\title{
Alvar Aalto and the theory of play: Through analysis on Alvar Aalto's furniture design
}

Mayu Kamamoto / Osaka University / Osaka / Japan

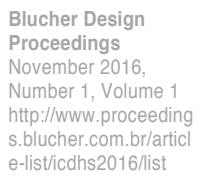

\begin{abstract}
Play was an important concept for Finnish architect and designer Alvar Aalto (1898-1976). He emphasized the importance of play in design activities. Aalto seems to have been influenced by Yrjö Hirn (1870-1952), a Finnish aesthetician and author of Barnlek [Child's play, 1916]. From the late 1920 s to 1940 s, Aalto designed not only buildings, but also furniture. In functionalism, which spread from the early 1920s, experimentation with wood for furniture played a very important role for Aalto. He emphasized that this experimentation was closely related to the idea of play. This study demonstrates Aalto's suggestive idea through an analysis of his furniture design. It can be said that the concept of play guided him to develop this idea.
\end{abstract}

\section{Keywords}

Alvar Aalto, Yrjö Hirn, play, furniture design, functionalism

\section{Introduction}

Alvar Aalto (1898-1976) was a Finnish architect and talented designer of furniture, glassware, lamps, and so on. He placed a lot of emphasis on play, a trait he shared with the Finnish aesthetician Yrjö Hirn (1870-1952). In 1916, Hirn wrote the book Barnlek [Child's play], where he explained the importance of play.

Aalto wrote an article entitled 'Koetalo, Muuratsalo' [Experimental house at Muuratsalo], published in the Finnish architectural journal Arkkitehti [Architect], where he stated the following:

Whether or not Yrjö Hirn was the direct cause, at any rate the influence of his personality contributed to my firm conviction and instinctive feeling that in the midst of our laboring, calculating, utilitarian age, we must continue to believe in the crucial significance of play when building a society for human beings, those grown-up children. (Aalto, 1953, Shildt [ed.], Alvar Aalto in his own words, 1998, p. 234)

It seems that perhaps this idea influenced him earlier. Aalto uses the word play to explain not only his architecture, but also his early furniture designs.

My research focuses on Aalto's furniture design, which he devoted himself to from the 1920s. Functionalism, which arose from the early 1920s, changed the state of the design field. Although Aalto was also influenced by this trend, he did not accept its rationalistic and mechanical character at face value. His furniture designs and wooden experiments indicate his unique, new ideal very well.

In this paper, firstly, I present an overview of design in the 1920s, when Aalto started working on furniture. It is said that Scandinavian countries blended modernism idea with their own identities, and Aalto was one of the most important figures at this time in Finland. Secondly, I focus on Aalto's furniture and examine his thesis by studying the changes in his design. Experiment enabled him to blend traditional material with new trend. Finally, I consider the role and meaning of play in his design activities, comparing him with Hirn. Aalto insisted on the importance of play when functionalism arrived, and this will be one example of how the idea of play still affects design today.

\section{Scandinavian functionalism}

In the early 1920s, the field of design in both America and Europe underwent a revolution: the age of modernism had come. In 1919, Bauhaus opened an academy, and in 1920, Le Corbusier heralded the machine age. In 1927, at the 
Weissenhofsiedlung Exhibition, functional buildings and apartments that featured white walls and flat roofs were created. In this way, the new style of the 1920s was shown to feature rational and technical aspects. Originally, it did not aim at a specific style, but it ended up creating a new one.

In the Scandinavian countries, it has been said that this functionalism as it was practiced did not succeed: instead, it was blended with their traditional crafts and materials. The Stockholm Exhibition of 1930 highlighted the nature of functionalism in the Scandinavian countries. Although this exhibition was based on modernist idea, it was intended to present "Better Things for Everyday Life," which the Swedish arts and crafts society had advocated. This revealed the need for beauty, mass production, and low-cost items for people's daily use.

In Finland, furniture designing was not an independent profession in the 1920s. Even large furniture companies used foreign designers, though at times a few pieces were designed by the factory owners themselves. After the late 1920s, however, the situation gradually changed and architects began to enter the field. Exhibitions were held one after another to display new furniture designs or new housing styles.

Aalto designed not only buildings, but also furniture: and he played a leading role in this new functionalism. However, he did not accept it at face value and searched for his own version.

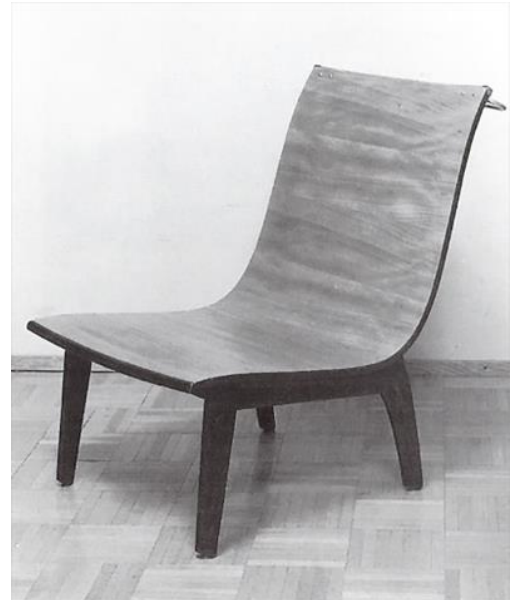

Fig.1: Alvar Aalto, Folk Senna, 1929, moulded one-piece seat

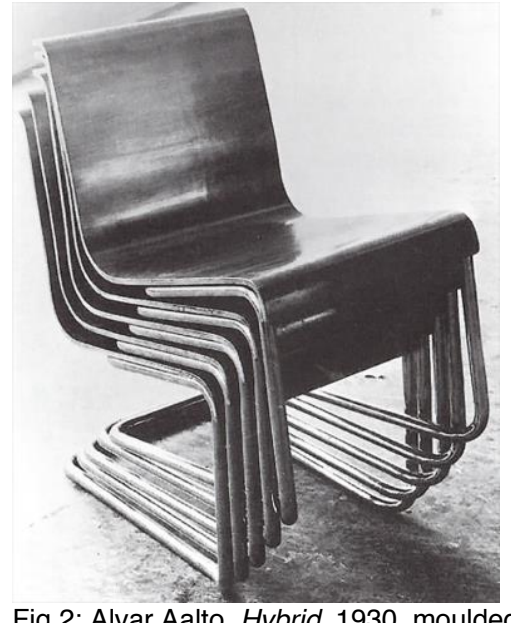

Fig.2: Alvar Aalto, Hybrid, 1930, moulded plywood Seat and metal pipe legs

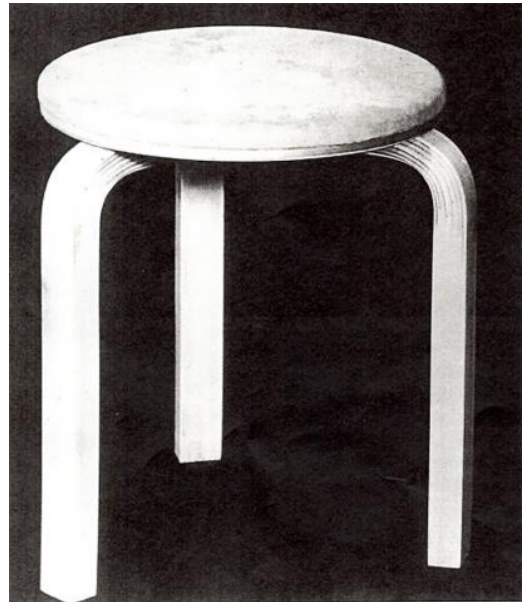

Fig.3: Alvar Aalto, stool 60, 1933, three Aalto legs

\section{Functionalism and humanizing Aalto's furniture designs}

Aalto designed several furniture patterns. Especially from the late 1920s to 1940s, he designed a number of wooden pieces. These works are still sold today at Artek, which was established in 1935 by Aalto and his wife and another couple. This period and the works he produced had a deep impact on Aalto's later design activity. If we conduct an overview of his designs, we find three important points that reveal his essential design concept.

In 1929, he exhibited a chair called Folk Senna [fig. 1] at a furniture exhibition in Turku. Its design was based on that of another chair called Senna by Erik Gunnar Asplund, which was exhibited at the International Exposition of Modern Industrial and Decorative Arts held in Paris in 1925. Its gently curving form, matching the shape of the human body, made it the first of its kind. This curved form was also used in Aalto's famous Paimio Chair. However, Folk Senna was not comfortable when sitting upright and was not suitable for mass production.

The next important change occurred in 1930, with the design of a chair called the Hybrid [fig. 2], which used metal pipes for the legs. The spring of the chair, like Marcel Breuer's Wassily chair with a wooden seat, enabled comfortable sitting and the metal pipes were suitable for mass production. However, Aalto immediately thought about replacing the metal pipe legs with wooden ones. That is, he felt that it was better to use wooden legs if the spring could be kept the same, because wood is visually more pleasing and comforting to the touch than a cold metal pipe.

In 1933, these changes gave rise to the famous feature called the Aalto Leg [fig. 3]. A feature of this leg was that it took into account the wood fiber's direction when bending the birch that was used [fig. 4]. Aalto considered this leg ideal from both a functional and aesthetic point of view and therefore considered it as an order of architecture. Thus, Aalto's furniture developed to satisfy all needs and cover practical problems such as cost and standards, comfort, and aesthetic appeal. Aalto was influenced by functionalism, but immediately he began to create his own style by using wood, which took into account function, human physiology, and aesthetic needs. 
Aalto blended traditional wooden material from his home country with new functionalism. Thus, he translated modernism principles into the language of the Finnish tradition of materials. He explained that this attempt succeeded as a result of play, and suggested play had meaning and importance.

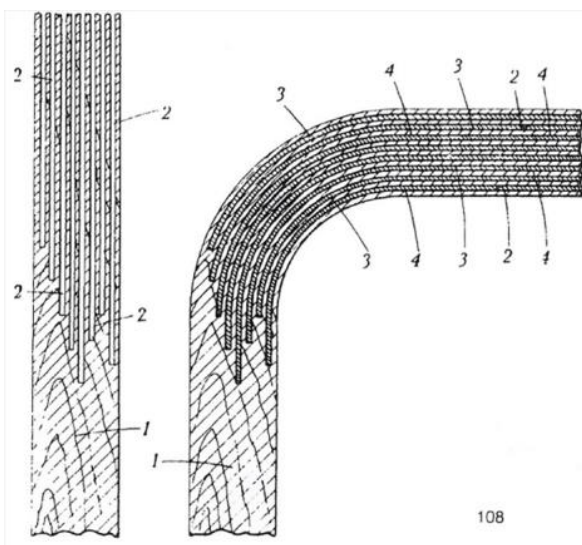

Fig.4: Drawing for Aalto's patent Application for the bent knee, 1933

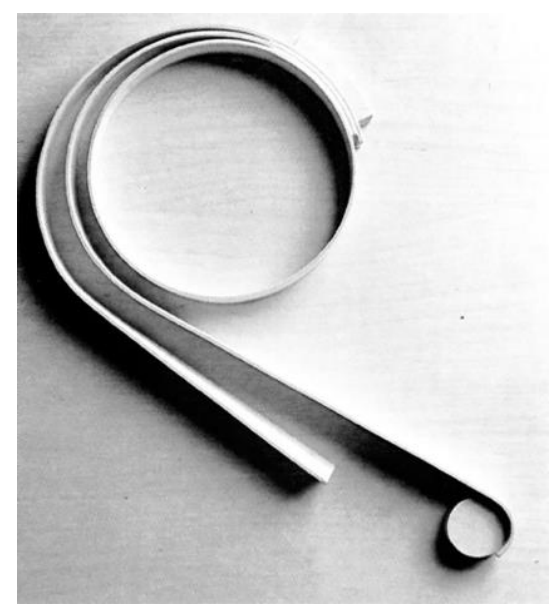

Fig.5: Alvar Aalto, wooden statue, undated

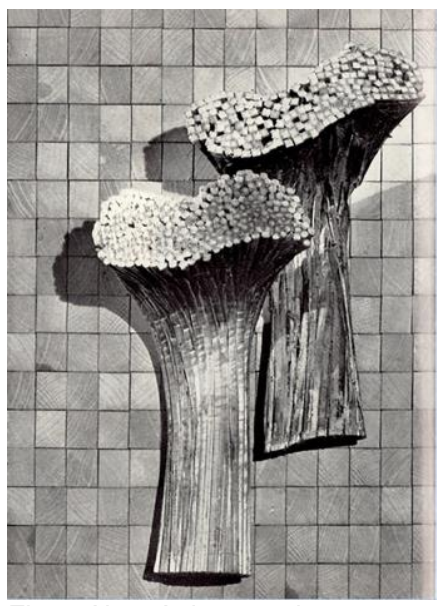

Fig.6: Alvar Aalto, wooden statue, 1947

\section{Aalto's experimentation: The role of play}

Aalto held several exhibitions of his furniture designs and received high praise. For example, at the Nordic Housing Fair in 1932, Arttu Brummer-Korvenkontio, a respected interior architect and resident critic for Domus magazine, esteemed Aalto's understanding of the nature of plywood and how his furniture suited the mind-set of the people of that era. In another case, Sigfried Giedion praised Aalto's vent plywood for its form and flexibility.

These evaluations were the fruit of Aalto's experimentation with wood. When he started designing furniture, he used birch wood, which was cheaper than beech in Finland, to make plywood furniture. In 1929, Aalto became acquainted with furniture maker Otto Korhonen (1884-1935), whose knowledge of plywood helped him begin his experimentation with the material, leading to furniture designs using birch wood.

This form of experimentation on materials was suggested by László Moholy-Nagy (1895-1946), who taught at Bauhaus. Moholy-Nagy emphasized the importance of using various materials to experiment on form, tactile sensation, surface treatment, and others. His thoughts on experimentation may have had a considerable influence on Aalto.

At his own exhibitions, Aalto presented wooden statues alongside his furniture [fig. 5]. As Philip Morton Shand stated, these statues played a role in making people realize that Aalto had come to understand the nature of wood through experimentation.

However, this was not enough, because not all of these forms and statues could be put to practical use. For example, the statue in 1947 [fig. 6] was made by putting birch sticks into a mold. However, this was not a useful technique, because the material fell apart according to the direction in which each fiber was molded. Aalto, however, explained that it was not an issue whether these statues were useful as furniture or architectural decorations, because they were only play. At an exhibition in Stockholm in 1954, he exhibited his furniture, light fixtures, textiles, and wooden statues. He explained:

It is my firm belief that this preliminary laboratory phase should be as free as possible, often actually totally free from utilitarian ends, for the desired results to be attained. In this exhibition, I have included some of my "experimental toys," some of which never led to any practically viable architectural details, remaining on the level of mere play. (Aalto, 'The constructive form exhibition in Stockholm, 1954', 1954, Shildt [ed.], Alvar Aalto in his own words, 1998, p. 258)

Thus, his wooden statues were considered meaningful not because of their practical applications, but their nonpractical ones: they were examples of mere play. His experiment related to play: then, what is play?

As mentioned above, Aalto noticed that he shared the idea of play with Hirn. Hirn, the Finnish aesthetician, published his most famous work, The Origins of Art, in 1900. In this, he explained the relation between play and art as advocated by Friedrich von Schiller and Karl Groos. Hirn stated:

Play and art have indeed many important characteristics in common. Neither of them has any 
immediate practical utility, but both of them do nevertheless serve some of the fundamental

needs of life. All art, therefore, can in a certain sense be called play. (Hirn, 1900, p. 28)

Here he points out that both play and art lack any practical utility, and this is their common nature; however, both of them can satisfy humans' fundamental need for pleasure. After this work, in 1916, Hirn published Barnlek and furthered his research on play. In a chapter about the circus, Hirn described that it is the acrobat's performance that brings spectators in and stimulates more senses than any other type of play, because the acrobat's mentality is perfectly irrational, unconscious, and reflective. He emphasized that the mind is free from rational calculation and conscious effort. If these calculations and efforts become a part of an acrobat's performance, his motion will stop.

Hirn considered this mind-set as the heart of play: and indicated it can provide artistic inspiration. He stated that the body, nerves, and senses are all inspired together in the mentality that is located in play: "In the literal sense, thinking and reflecting are deadly for acrobats, as they are in the figurative sense for poets and artists" (Hirn, 1916/ 1926, p. 215). Hirn emphasized that although technical training is absolutely essential for an acrobat, the vital factor is absorption.

Thus, the significance of play can be said to lie in its freedom from practical goals or utility. Aalto's argument for not centering his designs from a rational and technical standpoint seems to have been influenced by Hirn's play theory and forms the basis of his design thesis.

As seen above, experimentation was essential in helping Aalto apply traditional materials to his new functional style. However, Aalto emphasized playing over experimenting. He said: "Thus, we must combine serious laboratory work with the mentality of play, or vice versa" (Aalto, 'Experimental house at Muuratsalo', 1953, Shildt [ed.], Alvar Aalto in his own words, 1998, p. 234). Although an experimenting is related to using the right technique toward achieving the actual goal, he believed dealing with materials as a toy guides us to discover much more things.

Aalto's case shows that when we want to achieve a practical goal, we must free ourselves from actual goals: this is how to find the solution. The wooden statues exhibited along with his furniture embodied the role of play in his design work.

\section{Conclusion}

Scandinavian countries blended their own identities with modernism, creating what is sometimes called Scandinavian functionalism. Alvar Aalto was a significant figure in the Finnish version of this: and he emphasized that we must believe in the importance of play in the new functional age.

Through an analysis of his furniture design, I showed his ideal of associating traditional materials with new functional value. His designs were based on satisfying both functional and human needs. To accomplish this, experiments on materials were essential.

It can be said that the fruits of Aalto's furniture work were supported by the idea of play. He noticed the importance of connecting the mentality of play with experimentation. He dealt with materials in a free state of mind: that is, he played with wood materials. Although this design process seems Aalto's unique one, we can see his suggestive idea. Being influenced by Hirn's play theory, Aalto believed that we must be free from actual goals if we want to achieve practical goals; we must have the mind-set of a child at play.

\section{References}

Fleig, K. (1970) Alvar Aalto: 1922-1962, (Mühll, H. R. and Gleckman, W. B. trans.),

Hirn, Y. (1900) The origins of art: A psychological\& sociological inquiry, London: Macmillan and co.

Hirn, Y. (1916) Barnlek: Några kapitel om visor, danser och små teatrar [Children's play: Some chapters of songs, dances and small theaters], Helsinki: Söderström \& C: o.

Hirn, Y. (1918) Leikkiä ja taidetta: Muutamia lukuja lasten leluista, lauluista, tansseista ja pikku teatterista [Play and art: Some chapters of children's toys, songs, dances and small theaters], (Lehtonen, J. trans.), Porvoo: Werner Söderström. (Original work published 1916).

Hirn, Y. (1926) Les jeux d'enfants [Child's play], (Hammar, T. and Maury, L. trans.), Paris: Stock. (Original work published 1916).

Pallasma, J. (1985) Alvar Aalto furniture, Cambridge: The MIT Press.

Shildt, G. (ed.) (1994) Alvar Aalto: The complete catalogue of architecture, design and art (Binham, T. trans.), New York: Rizzoli. 
Shildt, G. (ed.) (1998) Alvar Aalto in his own words (Binham, T. trans.), New York: Rizzoli. Tukkanen, P. (ed.) (2002) Alvar Aalto designer, Helsinki: Alvar Aalto Foundation.

Zurich: Artemis.

\section{Biographical note}

Mayu Kamamoto was received the B.A degree in aesthetics from Osaka University, Osaka, Japan, in 2015. She is now a master course student of Osaka University. Her research interest includes the history of architecture and design in Finland. 